Volume 3

Number 1 Critical Perspectives on Marketing

from Japan - Part 1

2018

\title{
Skålén, Fougère \& Fellesson, Marketing Discourse: A Critical Perspective (2012)
}

Yuichiro Hidaka

Okayama University

Follow this and additional works at: https://digitalcommons.uri.edu/mgdr

Part of the Anthropology Commons, Economics Commons, Marketing Commons, Other Business Commons, and the Sociology Commons

\section{Recommended Citation}

Hidaka, Yuichiro (2018) "Skålén, Fougère \& Fellesson, Marketing Discourse: A Critical Perspective (2012)," Markets, Globalization \& Development Review. Vol. 3: No. 1, Article 5.

DOI: $10.23860 / M G D R-2018-03-01-05$

Available at: https://digitalcommons.uri.edu/mgdr/vol3/iss1/5

This Book Review is brought to you for free and open access by DigitalCommons@URI. It has been accepted for inclusion in Markets, Globalization \& Development Review by an authorized editor of DigitalCommons@URI. For more information, please contact digitalcommons-group@uri.edu. 
Skålén, Fougère \& Fellesson, Marketing Discourse: A Critical Perspective (2012) Cover Page Footnote

The author is grateful to MGDR editor Nikhilesh Dholakia and to MGDR reviewers for detailed help in the development of this review article. 


\section{Markets, Globalization \& Development Review}
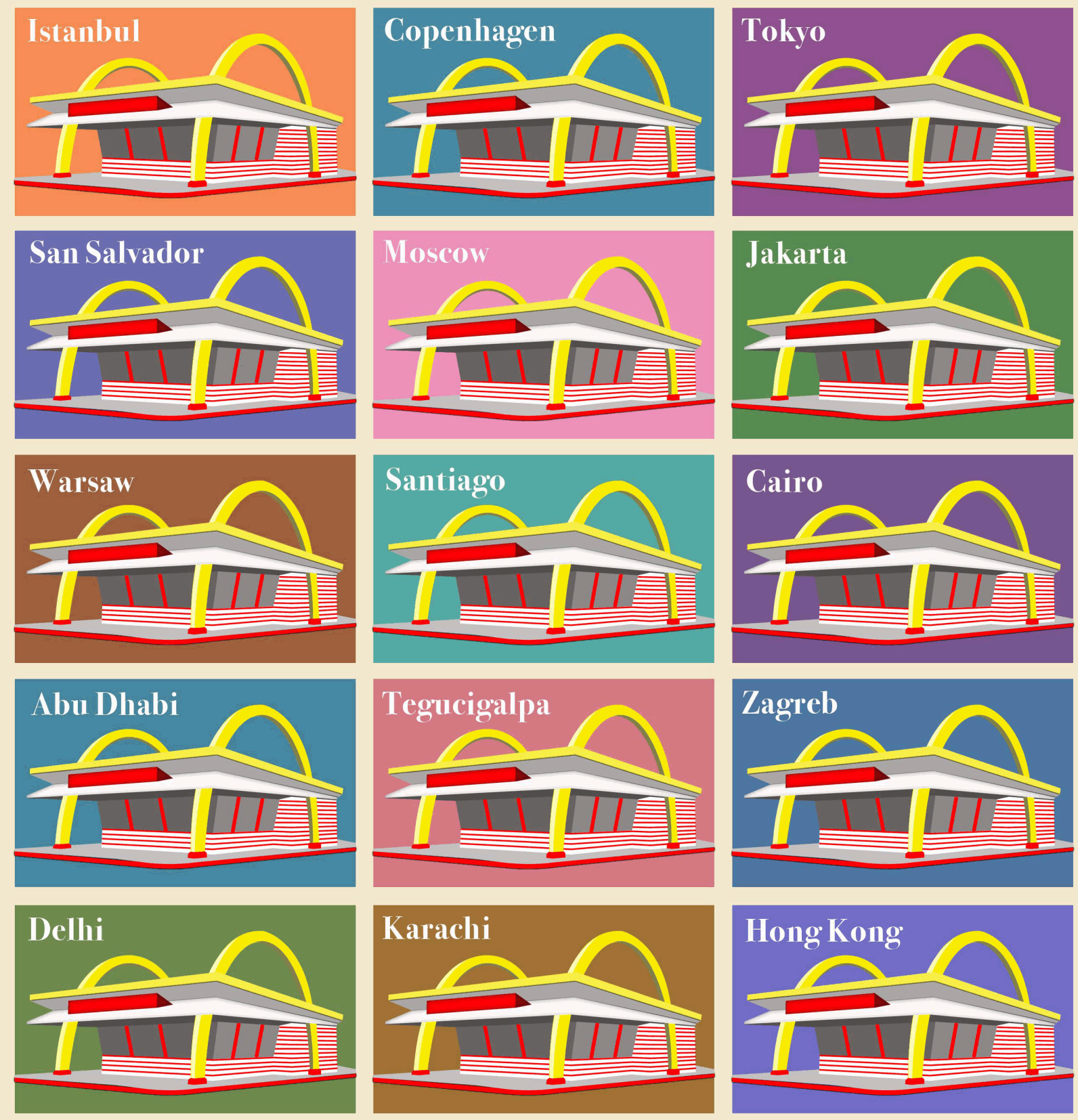

This book review is available in Markets, Globalization \& Development Review: https://digitalcommons.uri.edu/mgdr/ 


\section{Book Review \\ Skålén, Fougère and Fellesson - Marketing Discourse: A Critical Perspective (2012)}

Marketing Discourse is a book on the penetration process of the neoliberal managerialism in academic marketing discourse, written by three Scandinavian academics. Per Skålén is an Associate Professor of Business Administration at Service Research Centre in Karlstad University in Sweden. Martin Fougère is an Assistant Professor in the Department of Management and Organization at Swedish School of Economics and Business Administration, also known as Hanken, in Finland. Markus Fellesson is a Senior Lecturer in Marketing and Organization Studies at the Service Research Centre in Karlstad University in Sweden. This book clarifies how marketing theory has contributed to the penetration of neoliberal managerialism, and how this has affected human beings and societies. The book makes references to not only scholarly articles and books but also to works of marketing historians, to influential textbooks, and to texts by regulative organizations such as the American Marketing Association. The focus is on managerial academic marketing discourse that emerged in the early twentieth century and evolved throughout that century.

Marketing theory prescribes behavior of practitioners by providing technical knowledge. The prescribed behavior of practitioners functions as the basis for the governmental rationality of marketing theory. Furthermore, the governmental rationality is reinforced by practitioners actively reflecting on their practices and making references to the technical knowledge. This book shows that "marketing needs to be perceived as political discourse invested with power rather than as a positive science" (p. 3).

\section{A Foucauldian Approach}

In critically analyzing the penetration process of neoliberal managerialism in marketing, the authors rely on the Foucauldian concept of "governmentality" (Foucault 2000a) which holds that the penetration of power is closely involved with the dissemination of knowledge.

According to Foucault, power is realized by the dissemination of knowledge. Power has always taken discursive forms - it shapes and has been invested in discourses during modernity. Like scientific knowledge, discourse embedded in power forms knowledge and prescribes a person's behavior and defines the person's identity. For example, psychology 
prescribes what is normal or abnormal thinking by framing and controlling people's cognitions (Foucault 2003). In this way, knowledge functions not as a tool to describe practices, but as a tool for people to recognize practices in a specific way. As a result, the particular doctrine that the knowledge depends on, such as neoliberal managerialism, artfully predescribes people's behavior, and the governmental rationality is realized. Contrary to the Machiavelli's The Prince that sees the source of power as crushing and repressing something with a heavy hand, Foucault's governmentality shows that the governmental rationality is realized when people accept the knowledge embedded in the particular doctrine and reflect about their own practices themselves by making references to the doctrinaire knowledge.

\section{Disciplinary vs. Pastoral Power}

According to this perspective, the governmentality is realized by "disciplinary power" as well as "pastoral power".

Disciplinary power controls people by empowering people with authoritative knowledge as norms and standards, and urging people to take exemplary behaviors automatically. Knowledge functions as a behavioral norm of people. Comparison between the exogenous norm and actual practices clarifies the gap between practices by people and ideal possibility. It is possible to control people by urging them to close the gap between the actual position and the ideal position indicated by the knowledge.

Meanwhile, pastoral power controls people by promoting their own confession on the basis of the behavioral norms that knowledge indicates, in a manner similar to how a pastor relieves the doubts of believers. This power depends on the techniques for making individuals talk about themselves and their innermost thoughts. The individuals who talk about their own practices regulate themselves toward norms by proclaiming their innermost thoughts with or without the guidance of authorities. Managers as well as employees reflect on their own practices and improve their practices spontaneously and actively to fill the gap between the ideal norm and their own practices for their own benefits. In marketing - and in managerial fields in general - through a series of confessions and avowals, the patterned behavioral style and the neoliberal managerialism behind it advance and become pervasive.

As such, practices and technologies recommended by discourses function as "examinations", or evaluation criteria. Individual behavior is visualized by these evaluation criteria, and can be understood objectively. The evaluation criteria visualize the gap between actual self and possible ideal self, and make management or intervention easier. By such 
visualization, people become obedient and subordinate to the knowledge. Especially, pastoral power realizes the governance - even reaching to the innermost part of the person - because it attempts the infusion of the practitioner's voluntary confessions and functions into their way of thinking.

While disciplinary power governs from "the outside in" or by controlling deviations from the ideal norms indicated by knowledge, pastoral power governs from "the inside out", or comparing a subject's avowals to an external normative system (Varman, Saha and Skålén 2011, p. 1167). With this means, the legitimacy of neoliberal managerialism is enhanced and people are subject to exploitation to maintain and develop this legitimacy.

\section{Three Eras}

Based on the concept of governmentality, this book outlines three eras during which the processes by which neoliberal managerialism has deeply penetrated marketing discourse. Specifically, it shows that marketing has shifted from the managerialism based on disciplinary power to that emphasizing pastoral power.

Based on the scientific management of Taylor around 1910, managerialism in marketing first emerged. Taylorism influenced most the articulations of selling. Marketing discourses began to show that incorporating scientific management into marketing contributed to the realization of productive practices since 1910, especially for salespeople and their managers who faced customers in daily work. By the year 1920, the importance of customerism became widely known as a marketing concept. Especially, in the 1930s, the marketing concept became the dominant foundation, as the economic crisis forced practitioners to work in a more rational way. Journal of Marketing played a leading role in clearly showing and refining the importance of managerialism in marketing. With these marketing discourse based on scientific management, marketing changed from a field based on experience and intuition to a field where there was the ability for people to be trained, managed, controlled and developed (Chapter 5).

The governmental rationality of marketing, which had spread widely by the end of 1950s, has been reinforced gradually by the introduction of technical knowledge such as segmentation, targeting and marketing mix in marketing management. The provision of such technical knowledge aided the spread of neoliberal managerialism in practice as the provision of these technical knowledge functioned in ways to elaborate specific guidelines on how to develop ideological marketing concepts. The provision of these technical knowledge items significantly expanded the 
influence of neoliberal managerialism to embed it in the marketing concept (Chapter 6).

In the above process, the authors point out that neoliberal managerialism had penetrated by disciplinary power. Indeed, the development of marketing concept and technical knowledge contributed to making managers and employees aware of the gap between their practice and ideal norms. Such developments, however, affected primarily the creation of official organizational structures that were in charge of customer management rather than urging managers and employees to reflect on their practices. Indeed, the authors point out that the degree of penetration of neoliberal managerialism at this stage was still small.

It was the rise of services marketing in the 1970s that provided the decisive thrust for the penetration of neoliberal managerialism in marketing. Since the rise of services marketing, the penetration of neoliberal managerialism started relying on and shifting to pastoral power. The fundamental idea that services marketing discourse insisted on was that customer's evaluation of services were dependent not only on the substance of the offering but also on how the service was delivered by employees at the service encounter. Therefore, the management of employees from the viewpoint of customers was considered to be even more important, and became a key point related not just to the sales department but also to all departments.

In this case, pastoral technologies played an important role in accelerating the penetration of neoliberal managerialism. Various models were introduced that enabled managers and employees to self-reflect on their own practices. For example, the gap model, the customer satisfaction index, and so on worked effectively as tools to enable practitioners to make voluntary confessions. In addition to the fact that all the actions of all employees were subject to management for customers, various pastoral technologies were introduced as outcome indicators of their management. Practitioners began to reflect, voluntarily, on their practice for good customer services. The authors of this book attest that the neoliberal managerialism in marketing has penetrated the field fully nowadays by making full use of the foundation made by the earlier disciplinary power before the 1970s and exercising pastoral power after services marketing emerged in 1970s (Chapter 7).

In this way, marketing has strengthened its own governmentality and of neoliberal managerialism behind it. As their governmentality gets stronger, uncritical and unreflective applications of marketing theory to practices are more likely to occur. At the end of this book, the authors refer to the concept of moral distance by Bauman (1989) and show that 
uncritical application of marketing theory to practices in the era of strong governmentality can cause contradictory and problematic consequences. Bauman (1989) examines how the horrors of the holocaust were possible and reveals the bureaucracy that promoted these. Under the bureaucracy of those days, people sent to the holocaust centers were seen not as human beings but were only seen as figures in the statistical charts, such as inputs or outputs in the production process in organizations. Bauman points out that the biggest threat in bureaucratic organizations is being blind to the social influence that it potentially has. That is, "Bureaucracy objectifies and makes those consuming the products and services of bureaucratic organizations faceless. This creates a moral distance between organizations and the people consuming their services" (p. 159).

The services marketing technology replaces employees with numbers to serve, specifies the gap between standards and reality by providing behavioral standards, and proactively intervening in practice. Services marketing discourse controls employees by pointing that unachieved satisfaction is an important issue with reference to the numerical value of the customer satisfaction index, and treats customers as a means to manage employees (pp. 160-161). While these elevate the governmentality of marketing theory, which was supposed to create new possibilities of practices and neoliberal managerialism behind it, these also eliminate the possibilities of new practices.

\section{An Illustrative Case from Japan}

In Japan, the acceptance of foreign marketing theory started in 1955, when the Japan Productivity Center dispatched a team to visit and study US businesses. The executives of several Japanese leading companies, members of this team, reported on the importance of marketing. It led to wider recognition of the importance of overcoming the backwardness of Japanese companies' marketing by introducing marketing theory to Japan's then rapidly growing economy. After that, while continuing to be influenced by Japanese unique paradigm, which had emphasized the distribution and historical regularity (see Usui 2000 for details), marketing theory gradually diffused in Japan. In academic circles, such diffusion was mainly through, the Japan Society of Marketing and Distribution founded in 1951. In the world of practice, the Japan Marketing Association established in 1957 - aided the diffusion of marketing. Another factor aiding the diffusion was the growth of business schools, whose numbers and enrollments increased especially after 2000.

In more recent years, the penetration of marketing theory in Japan began to expand not only for commercial enterprises but also for tourism and in the public sector. For example, in tourism, the Japan Tourism 
Agency in the Ministry of Land, Infrastructure, Transport, and Tourism promotes the "Japanese Destination Management Organization (DMO)" for the purpose of improving the profitability of regional tourism. The creation of a Japanese DMO requires the approval from the Japan Tourism Agency (JTA), and - in 2018 - 70 corporations in various regions are authorized as DMOs. Particularly noteworthy is the fact that the authorization requires the formulation of marketing or brand strategy, the setting of the minimum essential Key Performance Indicators (KPIs), and the consecutive self-evaluation by the plan-do-check-act or PDCA cycle based on customer data. Furthermore, these KPIs contain not only the travel expenses and the number of guests in the region, but also the metrics that are emphasized in service marketing such as customer satisfaction or the rate of repeat visit. As indicated in the book being reviewed here, such KPIs and PDCA cycle play important roles in terms of urging practitioners to make their voluntary confessions - and continue to seek the benediction from JTA and the Ministry, the loci of pastoral power. This illustrative case shows that the penetration of marketing theory by pastoral power - as discussed in the book reviewed here - has made inroads in Japan as well.

\section{A Performative View of Marketing}

What the authors of this book point out is that "marketing is a performative science - 'a science that simultaneously describes and constructs its subject matter' ... one cannot separate science from practice, the discipline-knowledge from the discipline-control since, by definition, these sciences arise in and through practice" (p. 7). Marketing discourse not only explains marketing practices but also produces a view of marketing practices in line with those discourses, and has reproduced governmental rationality of neoliberal managerialism. The authors advocate that we need to re-recognize that marketing is a discourse in which practice and theory are unified, unlike the dichotomy between theory and practice.

Kevin Keller, a prominent scholar in brand management says that marketing or "branding is not rocket science. In fact, it is an art and a science (Keller 2007, p.19). Theory can change practitioner's viewpoint of practice and practice is constructed according to such viewpoints. As constructed practice changes, excellent marketing strategy should change. Therefore, he points out "there's always a creativity and originality component involved with marketing" (Keller 2007, p. 19). On the other hand, Keller still points out that excellent marketing enhances the chances of success in practice by providing guidelines to brand decision makers. 
Marketing theory is created on the premise of past practice. Or, in theory construction terms, the practice of creating (fresh) reality is forgotten. This book suggests that attention should be paid to the theorist's attempt to exaggerate one aspect in practice more than necessary. We often say "apply theory to practice". This view implies that theory is somewhat superior and practice follows it. This may be a discourse ignoring practitioners' creative power. According to this perspective, theory is an understanding to qualify the current situation, and what theory shows should not be very useful directly for practitioners who are interested in market creation. This book presents us the limitations and dangers of uncritical application of marketing theory to practice.

\section{Some Reflections from Japan}

Practice has possibilities to go beyond theory and overcome challenges in practice (Ishii 2009). On the other hand, it may be a misunderstanding to say that marketing theory has no meaning. Certainly, it is dangerous to think that marketing theory suggests something concrete for practice, or that application of theory results in immediate effects in practice. At the same time, however, theory should also be able to play a role in providing important cues for creative observations and revealing blind spots of practitioners (Ishii 2009).

Theory often appears in the stories of superior managers who have created new businesses. Masao Ogura, who created a home delivery business in Japan focusing on the concept of "delivery density" and Toshifumi Suzuki, who founded 7-Eleven in Japan focusing on the concept of "subdivision delivery and area dominant strategy", represent examples of practice-led sources of theory. The reason why these managers were able to focus on these concepts is that they discovered keys to such new businesses - and found ways to weaken the constraining existing frameworks. These managers used field-generated theory as a catalyst, and they could gain insights that revitalized their imagination and associative power to create something new. What made such moves possible was to dwell on both practice and theory. It does not mean that they analyzed subjects from outside of pre-determined frameworks. These cases show that these innovative managers understood the possibilities empathically or from the viewpoint of subjects without being influenced by the existing frameworks. Marketing theory thus could be an essential catalyst for practice.

\section{Concluding Comments}

The uncritical application of theory to practice narrows the possibility of practice. As the reviewed book shows, "academic marketing needs to be 
reformulated from prescribing how to do marketing to ... well, studying marketing. Marketing practice should be the object of study rather than the outcome of study" (p. 166). What is being suggested to marketing academia is not how to apply theory to practice but how to embrace and dwell on practice. We may be able to open up the possibility that marketing theory functions as an essential catalyst for practice by understanding the performative characteristics of marketing shown in this book. 


\section{References}

Bauman, Zygmunt (1989), Modernity and the Holocaust. Polity Press.

Dean, Mitchell (1999), Governmentality Power and Rule in Modern Society. Sage Publications.

Foucault, Michel (2000a), "Governmentality," in Power: The Essential Works of Foucault, Vol. 3, James D. Faubion ed., Free Press, 20122.

Foucault, Michel (2000b), "The Subject and Power," in Power: The Essential Works of Foucault, Vol. 3, James D. Faubion ed., Free Press, 326-48.

Foucault, Michel (2003), Abnormal: Lectures at college de France 1974-75. Palgrave.

Ishii, Junzo (2009), Business Insight: What is the Knowledge for Creation. Iwanami Shoten (in Japanese).

Keller, Kevin L. (2007), Strategic Brand Management, Third Edition. Prentice Hall.

Skålén, Per, Martin Fougère and Markus Fellesson (2012), Marketing Discourse: A Critical Perspective. Routledge.

The Japan Tourism Agency (2018), "the Japanese DMO" (accessed April, 27, 2018) [available at (in Japanese) http://www.mlit.go.jp/kankocho/page04 000053.html].

Usui, Kazuo (2000), “The Interpretation of Arch Wilkinson Shaw's Thought by Japanese Scholars," Journal of Macromarketing, 20 (2), 128-36. https://doi.org/10.1177/0276146700202002

Varman, Rohit, Biswatosh Saha and Per Skålén (2011), "Market Subjectivity and Neoliberal Governmentality in Higher Education," Journal of Marketing Management, 27 (11-12), 1163-85. https://doi.org/10.1080/0267257X.2011.609134 